\title{
UJI KUALITATIF DAN KUANTITATIF GOLONGAN SENYAWA ORGANIK DARI KULIT DAN KAYU BATANG TUMBUHAN Artocarpus dadah Miq.
}

\author{
Indarto \\ Pendidikan Fisika, FTK IAIN Raden Intan Lampung; e-mail: indartoalkimia @yahoo.com
}

\begin{abstract}
Abstrak: Sekarang ini kimia tumbuhan atau yang dikenal dengan fitokimia telah berkembang menjadi suatu disiplin ilmu tersendiri, yang berada di antara kimia organik bahan alam dan biokimia tumbuhan, serta mempunyai kaitan erat dengan keduanya. Bidang perhatian fitokimia adalah aneka ragam senyawa organik yang dibentuk dan ditimbun oleh tumbuhan, yaitu mengenai struktur kimiannya, biosintesisnya, perubahan serta metabolismenya, penyebarannya secara alamiah, dan fungsi biologinya. Penentuan secara kualitatif dapat memberikan informasi keberadaan senyawa atau golongan senyawa tertentu, dan kuantitatif memungkinkan kita membedakan mana komponen utama dan mana komponen tambahan dalam campuran. Tumbuhan A. dadah Miq. merupakan salah satu spesies dari Artocarpus. Uji yang dilakukan secara kualitatif meliputi uji tanin, saponin, flavonoid, steroid, terpenoid, dan kardiak glikosida. Uji kuantitatif meliputi uji fenol total, alkaloid, tanin, dan flavonoid. Dari uji yang telah dilakukan, sampel kulit batang positif mengandung senyawa tanin, saponin, flavonoid, terpenoid, alkaloid, dan kardiakglikosida. Sedangkan sampel kayu batang positif mengandung senyawa tanin, saponin, flavonoid, steroid, terpenoid, dan alkaloid. Sedangkan uji yang dilakukan secara kuantitatif meliputi uji fenol total, tanin, alkaloid, dan uji flavonoid. Dari uji ini, kandungan dalam kulit batang sebesar $0.0529 \%$ untuk fenol total, 27,7176 \% tanin, 9,455 \% flavonoid, dan 2,756 \% alkaloid. Sedangkan dalam kayu batang sebesar $0,5555 \%$ fenol total, 0,8987 \% tanin, 3,312\% flavonoid, dan 0,694\% alkaloid.
\end{abstract}

Kata kunci : artocarpus dadah, miq fitokimia,. 
PENDAHULUAN

Indonesia merupakan negara tropis yang kaya akan sumber daya alam terutama tumbuhan. Indonesia dikenal sebagai megabiodiversity terbesar kedua di dunia setelah Brasilia. Tumbuhan merupakan sumber bahan kimia hayati (chemical resources), sehingga biodiversitas dapat dipandang sebagai suatu industri atau pabrik bahan kimiawi yang berproduksi sepanjang tahun menghasilkan bahan kimia berguna (Chemical Prospectives) melalui proses rekayasa bioteknologi alami (Achmad dalam Ersam, 2001).

Sekarang ini kimia tumbuhan atau yang dikenal dengan fitokimia telah berkembang menjadi suatu disiplin ilmu tersendiri, yang berada di antara kimia organik bahan alam dan biokimia tumbuhan, serta mempunyai kaitan erat dengan keduanya. Bidang perhatian fitokimia adalah aneka ragam senyawa organik yang dibentuk dan ditimbun oleh tumbuhan, yaitu mengenai struktur kimianya, biosintesisnya, perubahan serta metabolismenya, penyebarannya secara alamiah, dan fungsi biologinya.

Pada semua pekerjaan tersebut diperlukan suatu metode pemisahan, pemurnian, dan identifikasi kandungan yang terdapat dalam tumbuhan yang memiliki sifat yang berbeda-beda dan juga memiliki jumlah yang banyak. Jadi, kemajuan pengetahuan kita mengenai fitokimia berkaitan langsung dengan keberhasilan memanfaatkan teknik yang sudah dikenal dan meneruskan pengembangan teknik baru untuk memecahkan suatu masalah baru yang menonjol (Robinson, 1995).
Senyawa kimiawi hasil isolasi dari tumbuhan banyak dimanfaatkan sebagai obat. Di indonesia spesies tumbuhan yang banyak dimanfaatkan sebagai obat salah satunya berasal dari famili Moraceae.

Moraceae merupakan suatu famili tumbuhan di alam yang merupakan produk dari keanekaragaman hayati di hutan tropik maupun subtropik. Salah satu genus dari famili ini adalah Artocarpus. Di indonesia sendiri Artocarpus banyak dimanfaatkan sebagai ramuan obat tradisional, misalnya bunga dari $A$. communis dimanfaatkan untuk mengobati sakit gigi, abu dari daunnya digunakan untuk mengobati sakit kulit, dan bagian daunnya digunakan untuk mengobati pendarahan. Begitu juga dengan kulit batang A. elastica yang digunakan untuk mencegah kehamilan, daunnya digunakan untuk obat tuberkolosis, sedangkan getahnya untuk obat disentri (Heyne, 1987 dalam Suhartati, 2001).

Tumbuhan A. dadah.merupakan salah satu spesies dari Artocarpus yang keberadaanya mulai langka di alam. $A$. dadah ini merupakan tumbuhan yang endemik hanya di Indonesia dan masih sedikit sekali orang yang meneliti. Sehingga diperlukan uji fitokimia lebih lanjut mengenai kandungan senyawa organik yang terdapat dalam tumbuhan ini, dalam hal ini dikhususkan bagian kulit dan kayu batangnya.

\section{BAHAN DAN METODE Bahan}

Bahan yang digunakan adalah serbuk sampel bagian kayu dan kulit 
batang tanaman Artocarpus dadah. Pelarut yang dipakai meliputi dietileter, etanol, etilasetat, metanol, aquades. Bahan kimia yang dipakai antara lain alumunium klorida $1 \%$, ammonia encer, ammonium hidroksida pekat dan encer, asam asetat anhidrida, asam asetat glasial, asam klorida $1 \%$, asam klorida $0,1 \mathrm{~N}$, asam sulfat pekat, butanol, fenol, besi(III)klorida $0,1 \%$, besi(III)klorida 0,1 M, kalium heksasianoferrat (III) 0,008 M, kloroform, minyak zaitun, tanin standar, pereaksi Meyer dan Wagner.

\section{Metode}

\section{Uji Kualitatif}

\section{Tanin}

Ke dalam gelas kimia dimasukkan sebanyak 0,5 gram serbuk sampel, kemudian ditambahkan $20 \mathrm{~mL}$ aquades lalu dididihkan dan disaring. Setelah itu $0,5 \mathrm{~mL}$ filtrat ditambahkan ferriklorida $0,1 \%$ dan diamati terjadinya perubahan warna.

\section{Saponin}

Ke dalam gelas kimia dimasukkan serbuk sampel sebanyak 2 gram, lalu ditambah dengan $20 \mathrm{~mL}$ aquades kemudian dididihkan lalu disaring. Diambil $10 \mathrm{~mL}$ filtratnya dan ditambahkan $5 \mathrm{~mL}$ aquades kemudian dikocok kuat hingga terbentuk busa. Lalu busanya ditambahkan 3 tetes minyak zaitun, setelah itu dikocok kembali dan diamati terbentuknya emulsi.

\section{Flavonoid 1}

Sebanyak 2 gram sampel dimasukkan ke dalam gelas kimia dan ditambah dengan $20 \mathrm{~mL}$ aquades kemudian dididihkan lalu disaring. 0,5 $\mathrm{mL}$ Filtratnya kemudian ditambah $5 \mathrm{~mL}$ ammonia encer dan $5 \mathrm{~mL}$ asam sulfat pekat dan diamati.

\section{Flavonoid 2}

Sebanyak 2 gram sampel dimasukkan ke dalam gelas kimia, lalu ditambah dengan $20 \mathrm{~mL}$ aquades kemudian dididihkan dan disaring. 0,5 $\mathrm{mL}$ Filtratnya ditambahkan 5 tetes aluminium klorida $1 \%$ dan diamati.

\section{Flavonoid 3}

Sebanyak 5 gram sampel dimasukkan ke dalam gelas kimia, lalu ditambahkan $10 \mathrm{~mL}$ etilasetat kemudian dididihkan dan disaring. $0,5 \mathrm{~mL}$ Filtratnya lalu ditambahkan $1 \mathrm{~mL}$ larutan ammonia encer, setelah itu diamati perubahannya.

\section{Steroid}

Ke dalam gelas kimia dimasukkan 2 gram sampel dan ditambah dengan $20 \mathrm{~mL}$ metanol yang mengandung $2 \mathrm{~mL}$ asam sulfat dididihkan dan disaring, setelah itu ditambahkan $2 \mathrm{~mL}$ asam asetat anhidrat, lalu diamati perubahannya.

\section{Terpenoid}

Ke dalam gelas kimia dimasukkan 2 gram sampel dan ditambahkan $10 \mathrm{~mL}$ etanol didihkan dan disaring, setelah itu diambil $5 \mathrm{~mL}$ ekstrak kemudian ditambahkan $2 \mathrm{~mL}$ kloroform dan $3 \mathrm{~mL}$ asam sulfat pekat, lalu diamati perubahannya.

\section{Kardiak glikosida}


Ke dalam gelas kimia dimasukkan 2 gram sampel dan ditambahkan $10 \mathrm{~mL}$ metanol dididihkan dan disaring, kemudian ditambahkan asam asetat glasial yang mengandung 1 tetes $\mathrm{FeCl}_{3} 1 \%$ dan juga ditambahkan asam sulfat pekat lalu diamati perubahannya.

\section{Alkaloid}

Sebanyak 3 gram sampel ditambah $10 \mathrm{~mL}$ larutan 0,05 $\mathrm{N}$ amoniakloroform. Kemudian campuran dikocok selama satu menit, kemudian disaring kedalam tabung reaksi. Kepada filtrat tersebut ditambahkan $5 \mathrm{~mL}$ $\mathrm{H}_{2} \mathrm{SO}_{4}$ dan dikocok dengan teratur, didiamkan sampai terbentuk dua lapisan. Lapisan atas (fase air) dipisahkan dan diuji dengan pereaksi Meyer dan Wagner.

\section{Uji kuantitatif}

\section{Uji fenol total}

Sebanyak 2 gram sampel ditambah $300 \mathrm{~mL}$ dietileter, lalu disoklet selama 2 jam untuk menghilangkan lemaknya. Setelah itu sampel sampel bebas lemak tersebut ditambahkan $50 \mathrm{~mL}$ dietileter dan dididihkan selama 10 menit, kemudian disaring. $5 \mathrm{~mL}$ ekstraknya ditambahkan $10 \mathrm{~mL}$ aquades, $2 \mathrm{~mL}$ ammonium hidroksida pekat, dan $5 \mathrm{~mL}$ n-butanol, dikocok lalu didiamkan hingga terbentuk dua fase dan sampai timbul warna. Kemudian diukur serapannya dengan spektrofotometer ultraungutampak pada panjang gelombang 255 nm.

\section{Tanin}

Sebanyak $500 \mathrm{mg}$ sampel dimasukkan ke dalam Erlenmeyer, lalu ditambahkan $50 \mathrm{~mL}$ aquades, diaduk dengan menggunakan pengocok mekanik selama 1 jam. Setelah itu larutan disaring dan dimasukkan ke dalam labu ukur $50 \mathrm{~mL}$ dan ditambahkan air hingga tepat tanda batas. Kemudian dipipet $5 \mathrm{~mL}$ filtrat ditambah $\quad 0,8 \quad \mathrm{~mL} \quad$ kalium heksasianoferrat(III) 0,008 $\mathrm{M}$ dalam 0,1 $\mathrm{N}$ asam klorida dan $0,8 \mathrm{~mL}$ ferriklorida 0,1 $\mathrm{M}$ dalam $0,1 \mathrm{~N}$ asam klorida. Kemudian didiamkan, setelah itu diukur serapannya dengan menggunakan spektrofotometer ultraungu-tampak pada panjang gelombang $420 \mathrm{~nm}$.

\section{Alkaloid}

Ke dalam gelas kimia $250 \mathrm{~mL}$, sebanyak 5 gram sampel ditambah 200 $\mathrm{mL}$ asam asetat $10 \%$ dalam metanol, lalu didiamkan selama 24 jam dan disaring. Kemudian dipekatkan dengan memanaskannya pada penangas air hingga volume menjadi $1 / 4$ volume awalnya. Setelah itu ditambahkan ammonium hidroksida pekat tetes demi tetes sampai terbentuk endapan sempurna. Larutan dibiarkan dan endapan tersebut dikumpulkan dan dicuci dengan ammonium hidroksida encer, lalu disaring dan dikeringkan lalu ditimbang beratnya.

\section{Flavonoid}

Dalam Erlenmeyer 10 gram serbuk sampel diekstrak dengan $100 \mathrm{~mL}$ metanol-air $80 \%$ pada suhu ruang selama 24 jam. Kemudian seluruh larutan disaring dan dipindahkan ke dalam krusibel. Lalu diuapkan hingga 
kering di atas penangas air kemudian ditimbang beratnya.

\section{HASIL DAN PEMBAHASAN Uji Kualitatif}

\section{Tanin}

Hasil uji tanin dari sampel kulit dan kayu batang dengan pereaksi $\mathrm{FeCl}_{3}$ $0,1 \%$ menunjukkan uji positif yaitu warna larutan menjadi kuning kehijauan untuk kulit batang dan cokelat kehijauan untuk kayu batang. Hal ini terjadi karena adanya reaksi reduksi.
Tanin merupakan golongan senyawa polifenol, polifenol mampu mereduksi besi (III) menjadi besi (II) (Budini, 1980). Hal ini juga merupakan cara klasik untuk mendeteksi senyawa fenol, yaitu dengan menambahkan larutan besi(III) klorida $1 \%$ dalam air atau etanol pada larutan cuplikan menimbulkan warna hijau, merah, ungu, biru atau hitam (Harborne, 1987)

Tabel 1. Data hasil uji kualitatif

\begin{tabular}{lcc}
\hline \multicolumn{1}{c}{ Uji } & Kulit Batang & Kayu Batang \\
\hline Tanin & + & + \\
Saponin & + & + \\
Flavonoid 1 & + & + \\
Flavonoid 2 & + & + \\
Flavonoid 3 & + & + \\
Steroid & - & + \\
Terpenoid & + & - \\
Kardiak Glikosida & + & + \\
Alkaloid (Meyer) & + & + \\
Alkaloid (Wagner) & + &
\end{tabular}

\section{Saponin}

Pada uji ini, $10 \mathrm{~mL}$ ekstrak sampel ditambah $5 \mathrm{~mL}$ akuades, kemudian dikocok hingga berbusa. Pada busa tersebut ditambahkan 3 tetes minyak zaitun kemudian dikocok kembali. Hal ini terlihat terbentuk emulsi dari kedua sampel tersebut. Hal ini menunjukan uji positif adanya senyawa saponin. Penambahan minyak zaitun disini sebagai sumber kolesterol, karena untuk memurnikan banyak saponin dengan menambahkan kolesterol, yang menyebabkan pembentukan senyawa kompleks adisi yang tidak larut dalam air (Robinson, 1995).

\section{Uji Flavonoid 1}

Dalam uji ini, 0,5 mL ekstrak sampel ditambah $5 \mathrm{~mL}$ amonia encer. Terlihat perubahan warna larutan menjadi agak kuning. Hal ini terjadi karena flavonoid termasuk dari senyawa fenol. Bila fenol direaksikan dengan basa akan terbentuk warna yang disebabkan terjadinya sistem konjugasi dari gugus aromatik (Markham,1988). 


\section{Uji Flavonoid 2}

Sebanyak $0,5 \mathrm{~mL}$ ekstrak sampel kulit dan kayu batang setelah ditambahkan 5 tetes $\mathrm{AlCl}_{3} 1 \%$ sampel berubah menjadi kuning. Hal ini menunjukan uji positif adanya senyawa flavonoid dalam sampel. Suatu sampel yang mengandung flavonoid, bila direaksikan dengan $\mathrm{AlCl}_{3}$ akan

terbentuk warna kuning, hal ini terjadi karena terbentuknya senyawa kompleks antara flavonoid dengan $\mathrm{AlCl}_{3}$ seperti pada Gambar 1 (Harborne, 1987).

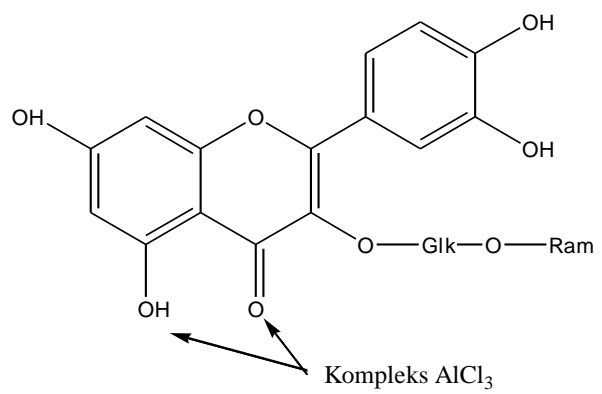

Gambar 1. Kompleks $\mathrm{AlCl}_{3}$ dengan flavonoid

\section{Uji Flavonoid 3}

Dalam uji ini sampel diekstrak dengan etiasetat, digunakannya etil asetat sebagai pelarut karena etil asetat merupakan pelarut yang baik untuk beberapa jenis flavonoid seperti katekin dan proantosianidin (Robinson,1995). Selain itu juga etilasetat merupakan pelarut yang baik untuk mendeteksi flavon dan flavonol (Harborne, 1987). Kemudian ekstrak sampel tersebut ditambah amonia encer, dan menghasilkan suatu larutan yang berwarna kuning kecoklatan untuk kulit batang dan warna kuning untuk kayu batang. Hal ini menunjukan uji positif adanya flavonoid.

\section{Steroid}

Sampel diekstrak dengan metanol yang mengandung $2 \mathrm{~mL}$ $\mathrm{H}_{2} \mathrm{SO}_{4}$, hasil ekstraksi tersebut kemudian ditambah dengan asam asetat anhidrat. Hasil yang diperoleh menujukkan terjadi perubahan warna larutan, untuk kulit batang warna larutan cokelat kemerahan dan kayu batang berwarna kuning kehijauan. Hal ini dapat disimpulkan bahwa sampel kulit batang menunjukan uji negatif dan kayu batang menunjukan uji positif. Uji positif adanya steroid apabila terjadi perubahan warna menjadi hijau atau biru, hal ini berdasarkan reaksi Liebermann-Buchard yang menyatakan bila suatu steroid direaksikan dengan asam asetat anhidrat dan setetes asam sulfat pekat akan menghasilkan warna hijau atau biru (Robinson, 1995).

Reaksi yang terjadi antara steroid dengan asam asetat anhidrat adalah reaksi asetilasi gugus $-\mathrm{OH}$ pada steroid. Sebagai contoh, senyawa $5 \alpha-$ Kolestan-3 $\beta$, 6 $\beta$-diol yang mengalami asetilasi pada gugus $-\mathrm{OH}$ pada $\mathrm{C} 3$, sehingga dihasilkan senyawa $3 \beta$ asetoksi-5 $\alpha$-Kolestan-6 $\beta$-ol (Ahmad, 1986), reaksinya dapat dilihat pada Gambar 2 berikut : 


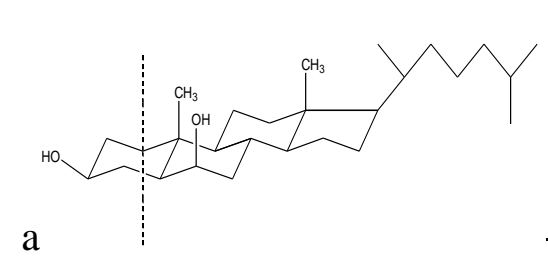

$\left(\mathrm{CH}_{3} \mathrm{CO}_{2} \mathrm{O}\right.$

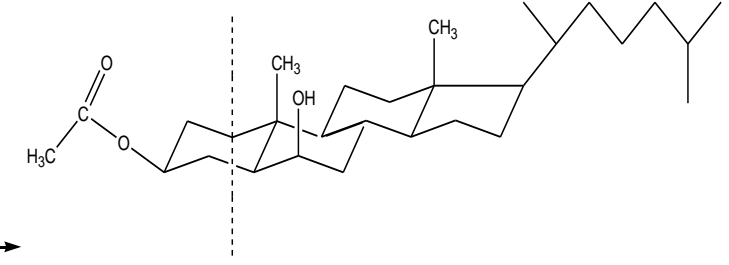

$\mathrm{b}$

Gambar 2. senyawa $5 \alpha$-Kolestan-3 $\beta, 6 \beta$-diol, b. senyawa $3 \beta$-asetoksi-5 $\alpha$ -

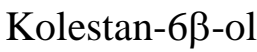

\section{Terpenoid}

Pada uji ini, sampel diekstrak dengan etanol, kemudian filtratnya ditambahkan kloroform dan asam sulfat pekat. Hasil yang teramati terbentuk warna cokelat kemerahan pada antarmuka. Pada kulit batang warnanya lebih pekat dari kayu batang. Hal ini menunjukan dalam kedua sampel tersebut mengandung senyawa terpenoid (Odeoga, 2005).

Terbentuknya warna cokelat kemerahan pada daerah antarmuka karena ditambahkan pereaksi asam klorosulfonat atau pereaksi Brieskorn \& Briner yang sering digunakan untuk membedakan secara khas triterpenoid yang berwarna merah dan senyawa steroid yang berwarna cokelat (Gerlach dalam Robinson, 1995) sehingga pada daerah antarmuka terlihat warna cokelat kemerahan.

\section{Kardiak glikosida}

Hasil ekstrak sampel dengan metanol ditambahkan asam asetat glasial yang mengandung 1 tetes $\mathrm{FeCl}_{3}$ $1 \%$ dan juga ditambahkan asam sulfat pekat. Dari reaksi tersebut terbentuk cincin cokelat kemerahan untuk kulit batang, sedangkan untuk kayu batang tidak terbentuk cincin berwarna. Hal ini menunjukan bahwa sampel kulit batang positif mengandung kardiak glikosida, sedangkan kayu batang menunjukan uji negatif.

Uji positif adanya kardiak glikosida adalah terbentuknya suatu lapisan cincin violet di bawah cincin cokelat dan akan nampak cincin hijau yang tipis, kardiak glikosida sendiri berada pada lapisan berwarna cokelat yang menunjukan adanya senyawa deoksi gula dan kardenolida.
Alkaloid
Dalam uji ini, sampel diekstrak dengan N-ammonia-kloroform kemudian disaring dan ditambahkan asam sulfat pekat yang tujuannya untuk menggaramkan alkaloid. Setelah itu dikocok sehingga terbentuk dua lapisan. Lapisan atas yang merupakan fase air diuji dengan pereaksi Meyer dan Wagner. Dari kedua uji ini menunjukan hasil yang positif, yaitu terbentuk endapan putih untuk uji Meyer dan endapan cokelat untuk uji Wagner. 


\section{Uji Kuantitatif}

Tabel 2. Data Uji Kuantitatif

\begin{tabular}{lll}
\hline Uji & Kulit Batang & \multicolumn{2}{c}{ Kayu Batang } \\
\hline Fenol total & $0.0529 \%$ & $0,5555 \%$ \\
Tanin & $27,7176 \%$ & $0,8987 \%$ \\
Flavonoid & $9,455 \%$ & $3,312 \%$ \\
Alkaloid & $2,756 \%$ & $0,694 \%$ \\
\hline
\end{tabular}

\section{Fenol total}

Dalam uji ini, sampel disoklet terlebih dahulu dengan eter selama dua jam, hal ini untuk menghilangkan kandungan lemak yang ada dalam sampel. Lemak bersifat non polar sehingga digunakan pelarut eter yang juga non polar. Kemudian sampel bebas lemak dilarutkan kembali dalam eter dan ditambahkan $\mathrm{NH}_{4} \mathrm{OH}$ dan n-butanol selanjutnya diencerkan dengan air, dikocok dan didiamkan hingga terbentuk dua fase. Fase organik dan fase air dipisahkan, fase air diukur absorbansinya dengan spektrofotometer UV/VIS pada panjang gelombang 255 nm. Sebelumnya disiapkan larutan standar fenol dengan konsentrasi 0, 10, 20, 40, 60 dan 80 ppm.

Dari hasil pengukuran dan dilakukan perhitungan, diperoleh kandungan fenol dalam sampel kulit batang sebanyak $1,058 \mathrm{mg}$ atau 0,0529 $\%$ berat sampel. Sedangkan kandungan fenol total dalam sampel kayu batang sebanyak $1,111 \mathrm{mg}$ atau $0,555 \%$ berat sampel. Dari data tersebut dapat diketahui bahwa kayu batang mengandung senyawa fenol lebih banyak dari pada kulit batang.

\section{Alkaloid}

Dalam uji alkaloid ini, sampel dimaserasi dengan asam asetat $10 \%$ dalam metanol. Hal ini bertujuan untuk mengekstrak alkaloid yang bersifat basa (Robinson, 1995). Hasil ekstrak ini kemudian dipekatkan hingga volumenya menjadi $1 / 4$ dari volume awal. Kemudian ekstrak tersebut dibasakan dengan menambahkan $\mathrm{NH}_{4} \mathrm{OH}$ sehingga alkaloid tersebut akan mengendap. Fungsi dari penambahan $\mathrm{NH}_{4} \mathrm{OH}$ adalah untuk mengendapkan alkaloid. Endapan tersebut dipisahkan dengan cara disaring dan kemudian dikeringkan, setelah kering ditimbang beratnya. Dari hasil pengerjaan ini, diperoleh berat alkaloid untuk sampel kulit batang sebesar 0,1378 gram atau $2,756 \%$ berat sampel. Sedangkan untuk sampel kayu batang sebesar 0,0347 gram atau 0,694\% berat sampel. Dari data tersebut dapat disimpulkan bahwa kandungan alkaloid dalam kulit batang lebih banyak dibandingkan dalam kayu batang.

\section{Tanin}

Pada uji ini, sampel dilarutkan dalam air dan dikocok dengan menggunakan pengocok mekanik selama satu jam. Kemudian disaring, 1 
mL ekstrak diencerkan hingga $10 \mathrm{~mL}$ kemudian ditambahkan pereaksi besi(III) klorida 0,1 $\mathrm{M}$ dalam asam klorida $0,1 \mathrm{~N}$, penambahan pereaksi ini dimaksudkan untuk mereduksi besi (III) menjadi besi (II). Setelah itu ditambahkan kalium heksasianoferrat(III) $\quad 0,008 \quad \mathrm{M}$ dalam asam klorida $0,1 \mathrm{~N}$ sehingga diperoleh larutan berwarna biru. Dalam hal ini, ion heksasianoferrat (III) mengoksidasi besi (II) menjadi besi (III) sehingga terbentuk heksasianoferrat (II).

$\mathrm{Fe}^{2+}+\left[\mathrm{Fe}(\mathrm{CN})_{6}\right]^{3-} \rightarrow \mathrm{Fe}^{3+}+\left[\mathrm{Fe}(\mathrm{CN})_{6}\right]^{4-}$

Kemudian ion-ion tersebut bergabung membentuk endapan yang berwarna biru turnbull.

$4 \mathrm{Fe}^{3+}+3\left[\mathrm{Fe}(\mathrm{CN})_{6}\right]^{4-} \rightarrow \mathrm{Fe}_{4}\left[\mathrm{Fe}(\mathrm{CN})_{6}\right]_{3}$

(Svehla, 1985)

Sebelum dilakukan pengukuran absorbansinya, larutan tersebut didiamkan sampai endapan biru yang terbentuk mengendap semua sehingga akan mempermudah dalam pengukuran. Pada pengukuran ini juga disiapkan larutan standar tanin dengan konsentrasi 0, 100, 200, 300, 400, dan 500 ppm. Setelah preparasi sampel dan larutan standar selesai, kemudian diukur absorbansinya dengan Spektrofotometer UV/VIS pada panjang gelombang 420 $\mathrm{nm}$.

Dari data yang diperoleh kemudian dilakukan perhitungan dengan persamaan regresi linear, sehingga diperoleh kandungan tanin dalam kuit batang sebesar 138,58 mg atau $27,7176 \%$ berat sampel. Sedangkan untuk kayu batang sebesar 4,4935 mg atau $0,8987 \%$ berat sampel. Dari data tersebut, terlihat bahwa kandungan tanin dalam kulit batang lebih banyak dari pada kayu batang.

\section{Flavonoid}

Dalam uji kuantitatif flavonoid, sampel dimaserasi selama 24 jam dengan metanol $80 \%$. Digunakannya metanol $80 \%$ untuk maserasi karena metanol $80 \%$ merupakan pelarut yang paling baik dan paling sering digunakan untuk ekstraksi flavonoid (Robinson, 1995).

Ekstrak disaring dan diuapkan pelarutnya hingga kering, sehingga diperoleh padatan kering flavonoid. Padatan flavonoid tersebut kemudian ditimbang beratnya. Untuk sampel kulit batang diperoleh berat flavonoid sebesar 0,9455 gram atau $9.455 \%$ berat sampel. Sedangkan untuk sampel kayu batang sebesar 0,3312gram atau 3,312\% berat sampel. Dari data tersebut, terlihat bahwa kandungan flavonoid dalam kulit batang lebih banyak dibandingkan dalam kayu batang.

\section{KESIMPULAN}

1. Kulit batang Artocarpus dadah mengandung senyawa organik diantaranya senyawa tanin, saponin, flavonoid, terpenoid, kardiakglikosida, dan alkaloid.

2. Bagian kayu batang Artocarpus dadah mengandung senyawa organik diantaranya senyawa tanin, 
saponin, flavonoid, steroid, terpenoid, dan alkaloid.

3. Senyawa organik yang paling banyak terkandung dalam kulit batang adalah tannin, yaitu sekitar $138,58 \mathrm{mg}$ atau $27,7176 \%$ berat sampel.

4. Kulit batang Artocarpus dadah memiliki kandungan tanin, alkaloid, dan flavonoid lebih banyak dari pada kayu batang.

5. Kandungan fenol total lebih banyak terdapat dalam kayu batang dari pada kulit batang.

\section{DAFTAR PUSTAKA}

Ahmad, S.A. 1986. Kimia Organik Bahan Alam. Penerbit Karunika Universitas Terbuka. Jakarta. Hal 65-73.

Ersam, T. 2004. Keunggulan Biodiversitas Hutan Tropika Indonesia dalam Merekayasa Model Molekul Alami. Makalah Seminar Nasional Kimia VI. Institut Teknologi Sepuluh November. Surabaya.

Harborne, J.B. 1987. Metode Fitokimia. Penuntun Cara Modern Menganalisis Tumbuhan. Alih bahasa Kosasih Padmawinata. ITB Bandung. Hal 1-107.

H. O. Odeoga, D. E. Okwu, and B. O. Mbaebie, Phytochemical constituents of some Nigerian medicinal plants, African Journal of Biotechnology Vol. 4(7), 685688, 2005.

Markham, K.R. 1988. Cara Mengidentifikasi Flavonoid.
Penerbit ITB. Bandung. Hal 1173.

Robinson, Trevor. 1995. Kandungan Organik Tumbuhan Tinggi. Penerbit ITB. Bandung. Hal 71285.

Suhartati, T. 2001. Senyawa Fenol Beberapa Spesies Tumbuhan Jenis Cempedak Indonesia. Disertasi. Penerbit ITB. Bandung.

Svehla, G. 1985. Buku Teks Analisis Anorganik Kualitatif Makro dan Semimikro. Alih bahasa Setiono dan Hadyana. PT. Kalman Media Pustaka. Jakarta. Hal 257. 